in reducing blood pressure. The latter warrants further study in hypertensive patients.

Tolamolol is a potent anti-anginal agent, preferable to practolol, and as effective as propranolol, but unlike propranolol it has the advantage of being cardioselective.

This project was generously supported by a Pfizer research grant, and Dr. Richard Walden'and Dr. E. A. Stevens provided invaluable help with co-ordination and supplies. We should like to thank Drs. Ronald Hartley and Max Zoob for referring patients to Brook General Hospital and are grateful to Mr. Michael Clarke for statistical help.

\section{References}

Adam, K. R., Pullman, L. G., and Scholfield, P. C. (1973). British fournal of Pharmacology, 49, 560 .

Adam, K. R. et al. (1974). European fournal of Pharmacology, 25, 170

Andersen, K. L., et al. (1971). Fundamentals of Exercise Testing. Geneva, World Health Organization.

Augstein, J., et al. (1973). Fournal of Medicinal Chemistry, 16, 1245.

Balcon, R. (1971). Postgraduate Medical fournal, 47, Suppl., p. 53 .

Barrett, A. M. (1971). Postgraduate Medical Fournal, 47, Suppl., p. 7. Beecher, H. K. (1955). Fournal of the American Medical Association, 159, 1602 .

Briant, R. H., et al. (1973). British fournal of Pharmacology, 49, 106.

Cardiology Today, 1973, 1, 2.

Dollery, C. T., Paterson, J. W., and Conolly, M. E. (1969). Clinical Pharmacology and Therapeutics, 10, 765

Dunlop, D., and Shanks, R. G. (1968). British fournal of Pharmacology, 32, 201 .

Felix, R., and Ive, R. A. (1974). British Medical fournal, 2, 333.

Fitzgerald, J. D. (1969). Clinical Pharmacology and Therapeutics, 10, 292.
Gillam, P. M. S., and Prichard, B. N. C. (1965). British Medical fournal, 2, 337.

Grant, R. H. E., et al. (1966). American fournal of Cardiology, 18, 361

Hebb, A. R., Godwin, T. F., and Gunton, R. W. (1968). Canadian Medical Association fournal, 98, 246.

Hillis, W. S., et al. (1974). British fournal of Pharmacology, 51, 15.

Holter, N. H. (1957). Annals of the New York Academy of Sciences, 65, 913. I.C.I. (1974), Personal communication

Kaltenbach, M. (1968). Beurteilung der Leistungereserven von Herzkranken mit Hilfe von Stufenbelastungen. Manhein, Boehringer.

Kannel, W. B., and Feinleib, M. (1972). American fournal of Cardiology, 29,154

Keelan, P. (1965). British Medical fournal, 1, 897.

Livesley, B., et al. (1973). British Medical fournal, 1, 375.

McNeill, R. S. (1964). Lancet, 2, 1101.

Miller, R. R., Amsterdam, E. A., and Mason, D. T. (1974). Rational Drug Therapy, 8, 1.

Ormrod, R. (1968). British Medical fournal, 2, 7.

Pfizer Ltd., (1973). Data on file.

Prichard, B. N. C. (1972). In New Perspectives in Beta-blockade, p. 153.

Horsham, CIBA Laboratories.

Prichard, B. N. C., Lionel, N. D. W., and Richardson, G. A. (1971). Postgraduate, Medical fournal, 47, Suppl., p. 59.

Rabkin, R., et al. (1966). American fournal of Cardiology, 18, 370.

Raftery, E. B., and Denman, A. M. (1973). British Medical fournal, 2, 452.

Reid, D. S., Pelides, L. J., and Shillingford, J. P. (1971). British Heart Fournal, 33, 370

Robinson, B. F. (1967). Circulation, 35, 1073.

Sandler, G. (1971). Postgraduate Medical fournal, 47, Suppl., p. 50.

Sandler, G., and Clayton, G. A. (1970). British Medical fournal, 2, 399.

Sharma, B., and Taylor, S. H. (1972). In New Perspectives in Beta-blockade. Horsham, CIBA Laboratories.

Sood, N. K., and Havard, C. W. H. (1973). Thorax, 28, 331

Sowton, E., and Hamer, J. (1966). American fournal of Cardiology, 18, 317.

Sowton, E., et al. (1968). British Medical fournal, 1, 215.

Stephen, S. A. (1966). American fournal of Cardiology, 18, 463.

Thadani, U., et al. (1973). British Medical fournal, 1, 138.

Wiseman, R. A. (1971). Postgraduate Medical Yournal, 47, Suppl., p. 68

Wolfson, S., et al. (1966). American fournal of Cardiology, 18, 345.

World Health Organization (1959). Technical Report Series, No. 168.

\title{
Relationship of Posture and Age to Urinary Protein Excretion
}

\section{SAKHARAM D. MAHURKAR, VASANT GANDHI \\ GEORGE DUNEA, \\ VEERASAMY K. G. PILLAY, \\ HARRY LEVINE,}

British Medical fournal, 1975, 1, 712-714

\section{Summary}

The influence of posture and age on urinary protein excretion was studied in 120 normal men volunteers. The supine excretion rate was less than $140 \mu \mathrm{g} / \mathrm{min}$ in all but two people (median value $38 \mu \mathrm{g} / \mathrm{min}$ ) and tended to increase with age. The excretion rate decreased on quiet standing in $\mathbf{8 0} \%$ of people, which corresponded to a fall in creatinine clearance. In the remaining $20 \%$ protein excretion increased on standing but generally remained within normal limits and was dissociated from changes in creatinine clearance. This increase was more prevalent in younger people and may represent a phenomenon analogous to orthostatic proteinuria, differing only quantitatively.

\footnotetext{
Division of Nephrology and Hypertension, Cook County Hospital, Chicago, Illinois 60612

SAKHARAM D. MAHURKAR, M.D., Deputy Director of Division GEORGE DUNEA, M.B., M.R.C.P., Director of Division

HARRY LEVINE, M.A., Biostatistician

VEERASAMY K, G. PILLAY, M.R.C.P., F.C.P., Staff Nephrologist (Present aERASAMY K. G. PILLAY, M.R.C.P., F.C.P., Staff Nephrologist (Present appointment: Chief of Section

VASANT GANDHI, M.B., B.s., Staff Nephrologist (Present appointment: Staff Physician, Veterans Administration Hospital, Hines, Illinois)
}

\section{Introduction}

Since abnormal amounts of protein in the urine probably indicate renal disease it is important to know the normal range of protein excretion. Wide variations in the upper limit of normal (Savory et al., 1968) reflect not only the different methods of measuring total protein but also inherent inaccuracies in urine collections and the effect of factors such as posture, exercise, exposure to heat or cold, and emotional stress. We report here a study in which we tried to clarify the picture by eliminating some of these variables by standardizing the procedure (Pillay et al., 1972) and by relating protein excretion to posture and age.

\section{Subjects and Methods}

The 120 healthy male volunteers studied were allocated to one of three groups of 40 according to their age. Group 1 (24-36 years) consisted mainly of interns and residents, group 2 (18-23 years) of college students, and group 3 (11-17 years) of schoolchildren. Women were excluded because of difficulties in obtaining uncontaminated urine.

All volunteers were studied in a room under the close supervision of an attendant. Each test was preceded by an equilibration period of lying supine for 15 to 30 minutes, at the end of which urine was collected and discarded. Each person then lay supine for one hour and spent a second hour standing quietly in an easy but not deliberately lordotic or kyphotic posture. Gentle walking was allowed during the period of standing. Each person drank $200 \mathrm{ml}$ of water at the beginning of each period. Urine was collected at the end of each period by voiding. Blood for analysis was taken halfway through the study from people in groups 1 and 2 but not from those in group 3. Two 
subjects were studied lying down for one hour and then standing for six consecutive one-hour periods to determine the influence of prolonged standing.

Urinary protein was measured by a modified biuret method (Savory et al., 1968), urinary albumin by radial immunodiffusion in 18 subjects (Mancini et al., 1965), serum and urine creatinine by Jaffe's picric acid method (Bosnes et al., 1945). Protein excretion rate was calculated and expressed in $\mu \mathrm{g} / \mathrm{min}$. Creatinine clearance was measured only in subjects in groups 1 and 2. Standard statistical formulae were used in all computations.

\section{Results}

Supine Protein Excretion.-The distribution of the supine protein excretion rates (fig. 1) was strongly skewed to the right, with a mode of $20 \mu \mathrm{g} / \mathrm{min}$ and a median of $38 \mu \mathrm{g} / \mathrm{min}$. There were two outliers. These people excreted $185 \mu \mathrm{g} / \mathrm{min}$ and 203 $\mu \mathrm{g} / \mathrm{min}$ respectively and, short of further detailed examination, were best classified as atypical. The range for the other volunteers was $5-142 \mu \mathrm{g} / \mathrm{min}$.

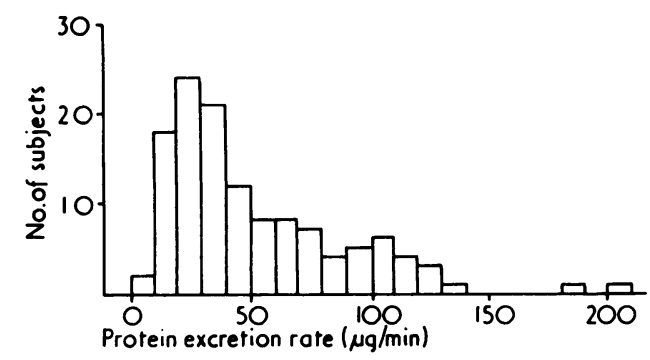

FIG. 1 -Supine protein excretion rates in 120 normal subjects.

Protein Excretion on Standing.-Protein excretion decreased in $97(81 \%)$ out of 120 people on assuming the upright position (fig. 2). The distribution of the percentage changes among the 97 was relatively symmetrical, the median change being $-43 \%$ and the mode $-45 \%$, while the distribution of percentage changes among the 23 subjects whose protein excretion increased was highly irregular, with a range of $7 \%$ to $316 \%$. Standing protein excretion remained below $140 \mu \mathrm{g} / \mathrm{min}$ in all but two persons, in whom the rates were $193 \mu \mathrm{g} / \mathrm{min}$ and $223 \mu \mathrm{g} / \mathrm{min}$. In two other people, not included in the series, standing protein excretions were $350 \mu \mathrm{g} / \mathrm{min}$ and $660 \mu \mathrm{g} / \mathrm{min}$ but supine protein excretion was normal.

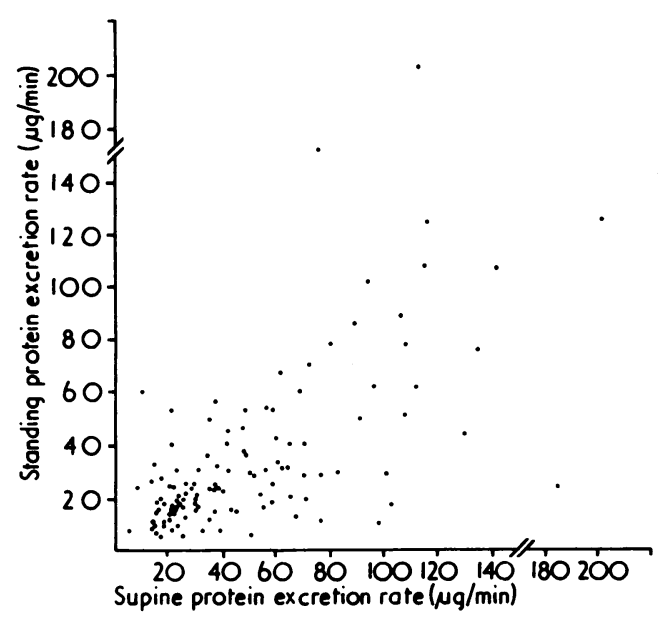

FIG. 2-Effect of standing on protein excretion in 120 normal subjects.

Creatinine Clearance.-Creatinine clearance decreased on standing in $72(90 \%)$ of the 80 persons in groups 1 and 2 , with a median change of $-29 \%$ and a mode of $-15 \%$. In those people whose protein excretion decreased on standing the correlation between percentage changes in protein excretion and creatinine clearance was positive $(\mathrm{r}=0.5 ; \mathrm{P}<0.001)$ (fig. 3 ). In the two persons in whom the effect of prolonged standing was studied the standing protein excretion rates were consistently lower than the initial supine value (fig. 4). The percentage changes in albumin excretion closely followed those of the total urinary protein $(\mathrm{r}=0.94 ; \mathrm{P}<0.001)$. Urinary volume decreased on standing in all but three people, with a median change of $-49 \%$, a mode of $-35 \%$, and a range from $-4 \%$ to $-87 \%$.

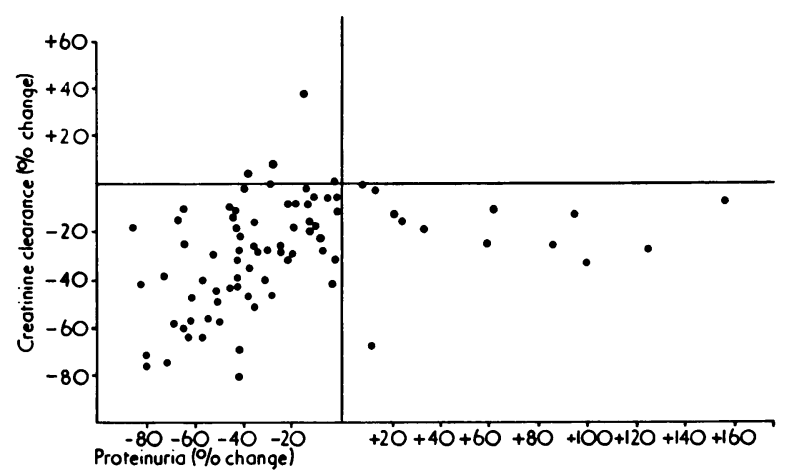

FIG. 3-Changes in protein excretion and creatinine clearance on standing in 80 normal subjects in groups 1 and 2.

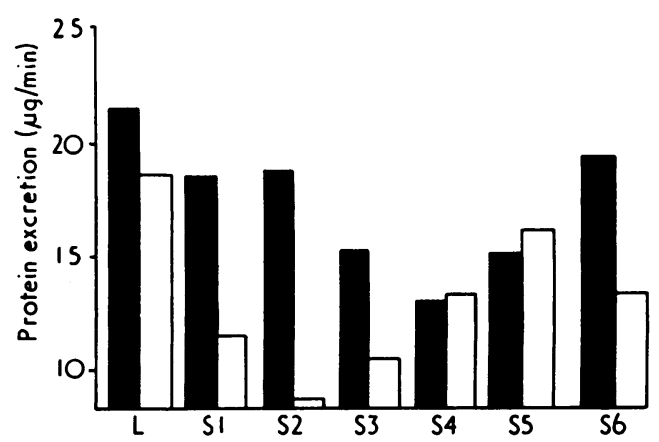

FIG. 4-Effect of prolonged standing on protein excretion in two subjects. Numbers indicate consecutive hours of standing. $L=L y i n g . ~ S=S t a n d i n g$.

Protein Excretion and Age.-Supine protein excretion tended to increase with age. For all the people there was a small but significant correlation between protein excretion and age $(r=0.25 ; P<0.01)$. This was also indicated in the linear regression formula: protein excretion $=26+1 \cdot 1 \times$ age in years. The protein excretion rates were lowest in subjects in group 3 (median $33 \mu \mathrm{g} / \mathrm{min}$ ) and highest in those in group 1 (median $56 \mu \mathrm{g} / \mathrm{min}$ ). In those in group 2 the median was $37 \mu \mathrm{g} / \mathrm{min}$. On assuming the upright position no effect of age was detected in persons in whom protein excretion decreased on standing. Nevertheless, the proportion of people whose protein excretion increased on standing was higher in groups $2(28 \%)$ and $3(25 \%)$ than in group $1(5 \%)$-the difference being significant on application of $\chi^{2}$ test $(P<0.025)$.

\section{Discussion}

All but two of our volunteers excreted less than $140 \mu \mathrm{g}$ protein/ min when supine. Excretion tended to increase with age. In the upright position protein excretion increased in only $20 \%$ of the volunteers, and this was also an age-related phenomenon. We had shown that the rate of protein excretion decreases on stand- 
ing in most patients with severe or mild proteinuria (Sharma et al., 1971; Mahurkar et al., 1973) and also when some of the haemodynamic effects of standing were simulated by the application of venous tourniquets to the thighs in the supine position (Gandhi et al., 1971). Our present results are in line with the findings in these studies though at variance with those of others (Robinson et al., 1964; Relman et al., 1971; Rennie, 1971). We found that protein excretion decreased on standing upright, with a corresponding fall in creatinine clearance, in $80 \%$ of people. The remaining $20 \%$ were mostly younger persons in whom an increase in protein excretion was dissociated from changes in creatinine clearance.

Our study emphasizes the pre-eminence of glomerular filtration in regulating protein excretion in most normal people, since the fall in protein excretion results from a reduced filtered load. But a different mechanism must govern the increase in protein excretion when glomerular filtration falls. A partial failure of renal tubular reabsorption of filtered proteins has been postulated in exercise proteinuria (Poortmans, 1972; Pollak et al., 1974) but has not been looked at in studies on posture. Increased glomerular permeability to protein from raised venous pressure has been suggested as the cause of orthostatic proteinuria (Bull, 1948/49), and this may also be the case in subjects whose protein excretion increases on standing but remains within normal limits.

Orthostatic proteinuria has been defined broadly as "a laboratory syndrome whose diagnosis requires the absence of qualitative proteinuria during recumbency and its presence during quiet ambulation or standing" (Robinson, 1970). On those criteria orthostatic proteinuria has been encountered in $5-20 \%$ of people (Robinson, 1964; Hamburger, 1968), but this finding may reflect the practice of estimating protein in the urine qualitatively and with variable fluid intake. Under these conditions the urine may be concentrated and the protein ap- parently raised on standing. In our study, in which fluid intake and the period of observation were the same in all people studied, the incidence of true orthostatic proteinuria was around $3 \%$. Nevertheless, we found a much larger group $(20 \%)$ in whom protein excretion increased on standing but remained within normal limits. This phenomenon, like orthostatic proteinuria, was commoner in younger people. Conceivably it may differ from true orthostatic proteinuria only quantitatively and may reflect the existence of a wider distribution curve for protein excretion when standing

We thank Mr. J. Becktal and Dr. A. Johnson, statisticians of Hines-VA Cooperative Studies Program Research Center, Hines, Illinois, for their help with statistical analysis.

\section{References \\ Bosnes, R. W., and Taussky, H. H. (1945). Journal of Biological Chemistry, \\ 158, 581.
Bull, G. M., (1948/1949). Clinical Science, 7, 77. \\ Gandhi, V. C., et al. (1971). Proceedings of the American Society for Nephrology, 4,25 . \\ Hamburger, J. (1968). In Nephrology, vol. 1, p. 114. Philadelphia, Saunders. Mahurkar, S. D., et al., (1973). Clinical Research, 21, 698. \\ Mancini, G., Carbonara, A. O., and Heremans, J. F., (1965). Immuno- chemistry, 2, 235. \\ Pillay, V. K. G., et al. (1972). Archives of Internal Medicine, 130, 90. \\ Pollak, V. E., First, M. R., and Pesce, A. J. (1974). Nephron, 13, 82. \\ Poortmans, J. R. (1972). Clinical Science, 43, 115. \\ Relman, A. S., and Levinsky, N. G. (1971). In Diseases of the Kidney, ed. M. B. Strauss and L. G. Welt, 2nd edn., p. 87. Boston, Little, Brown. Rennie, I. D. (1971). Medical Clinics of North America, 55, 213. \\ Robinson, R. R., and Glenn, W. G., (1964). Fournal of Laboratory and Clinical Medicine, 64, 717. \\ Robinson, R. R., (1970). In Proteins in Normal and Pathological Urine, ed. Y. Manuel, J. P. Revillard, and H. Betuel, p. 224. Karger, New York. \\ Savory, J., Pu, P. H., and Sunderman, F. W., jun. (1968). Clinical Chemistry, $14,1160$. \\ Sharma, B. K., et al. (1971). Lancet, 1, 369.}

\section{Serum $\alpha$ - Fetoprotein Levels in Patients with Cystic Fibrosis and their Parents and Siblings}

\footnotetext{
Janeway Child Health Centre and Memorial University of Newfoundland, St. John's, Newfoundland, Canada

R. K. CHANDRA, M.D., F.C.C.P., Professor of Paediatric Research K. MADHAVANKUTTY, PH.D., Biochemist

R. C. WAY, M.D., F.R.C.P., Associate Professor of Paediatrics
}

\section{Introduction}

Cystic fibrosis (C.F.) is the commonest lethal genetic disease in white Caucasians, occuring in about 1 in 2000 live births (Danks et al., 1965; Brunecky, 1972). The gene frequency is estimated to be $2-5 \%$. Obviously the mutation rate must be high or some heterozygote advantage must exist to keep the gene frequency at such a high level. In other ethnic groups C.F. is relatively rare (Wright and Morton, 1968). The inheritance is on a simple Mendelian autosomal recessive pattern but the possibility of more than one mutant allele has been suggested (Danes and Bearn, 1969). The main difficulty of providing adequate genetic counselling to relatives of children with C.F. other than the parents, who must be obligate heterozygotes of C.F. genes, is the failure in identifying with certainty asymptomatic carriers.

In C.F. the cell membrane metabolism and ion transport across it are abnormal, which might explain the changes in electrolyte content of sweat and other secretions. Glycoproteins in the membrane and secretions are suspected to be abnormal in chemical structure and charge. Lungs, pancreas, and liver are affected, and frequent pulmonary infections, especially with pseudomonas, are the main cause of morbidity and mortality. The multisystem involvement, which includes gut-associated organs, suggests a failure of optimal embryonic development which may be associated with persistent production of proteins 